\title{
WELL-BEING AND MENTAL HEALTH IN THE GIG ECONOMY
}

Policy Perspectives on Precarity

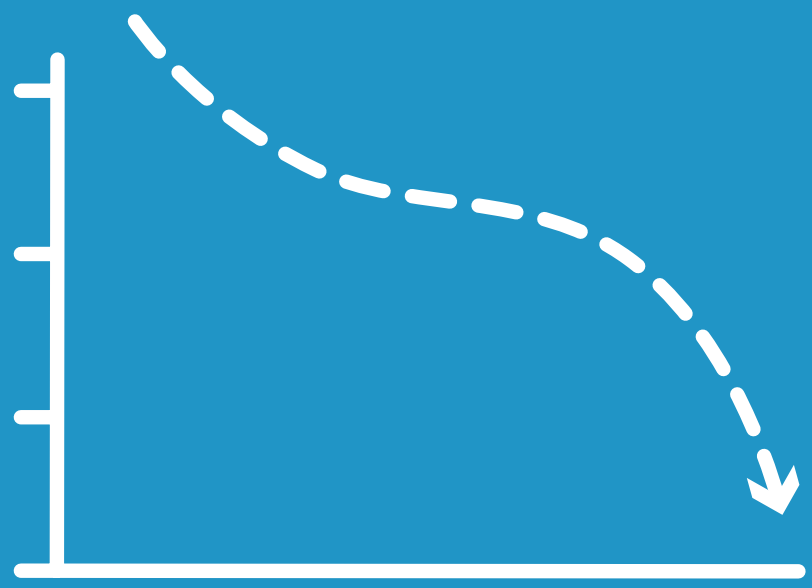

SALLY-ANNE GROSS GEORGE MUSGRAVE and LAIMA JANCIUTE CAMRI Policy Briefs 4

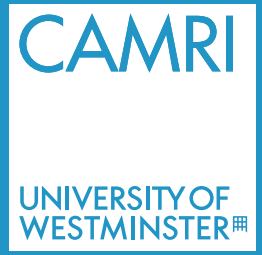




\section{THE AUTHORS}

SALLY-ANNE GROSS is Principal Lecturer in Music Business Management, School of Media, Arts and Design, University of Westminster and a music manager. With George Musgrave she authored the two-part study nationwide study 'Can Music Make You Sick?'.

Dr GEORGE MUSGRAVE is Senior Lecturer in Music Business Management, School of Media, Arts and Design, University of Westminster and a musician. With Sally-Anne Gross he authored the two-part study nationwide study 'Can Music Make You Sick?'.

DR LAIMA JANCIUTE was Research Fellow of the Policy Observatory at the Communication and Media Research Institute (CAMRI), University of Westminster.

\section{ABOUT CAMRI}

\section{CAMRI \\ UNIVERSITYOF WESTMINSTER ${ }^{\text {I }}$}

CAMRI (the Communication and Media Research Institute) at the University of Westminster is a world-leading centre of media and communication research. It is renowned for critical and international research that investigates the role of media, culture and communication(s) in society.

CAMRl's research is based on a broader purpose and vision for society: its work examines how the media and society interact and aims to contribute to progressive social change, equality, freedom, justice, and democracy. CAMRI takes a public interest and humanistic approach that seeks to promote participation, facilitate informed debate, and strengthen capabilities for critical thinking, complex problem solving and creativity.

\section{camri.ac.uk}




\section{SERIES DESCRIPTION}

The CAMRI Policy Brief series provides rigorous and evidence-based policy advice and policy analysis on a variety of media and communicationrelated topics. In an age where the accelerated development of media and communications creates profound opportunities and challenges for society, politics and the economy, this series cuts through the noise and offers up-to-date knowledge and evidence grounded in original research in order to respond to these changes in all their complexity.

By using Open Access and a concise, easy-to-read format, this peerreviewed series aims to make new research from the University of Westminster available to the public, to policymakers, practitioners, journalists, activists and scholars both nationally and internationally.

\section{camri.ac.uk/policy-observatory}

\section{CAMRI Policy Briefs (2018)}

\section{Series Editors:}

Professor Steve Barnett

Professor Christian Fuchs

Dr Anastasia Kavada

Nora Kroeger

Dr Maria Michalis

THE ONLINE ADVERTISING TAX: A Digital Policy Innovation Christian Fuchs

ARTIFICIAL INTELLIGENCE AND THE INTERNET OF THINGS Mercedes Bunz and Laima Janciute

APPEARANCE, DISCRIMINATION AND THE MEDIA

Diana Garrisi, Laima Janciute, and Jacob Johanssen

WELL-BEING AND MENTAL HEALTH IN THE GIG ECONOMY Sally-Anne Gross, George Musgrave and Laima Janciute

\section{CAMRI extended policy report (2018)}

THE ONLINE ADVERTISING TAX AS THE FOUNDATION OF A PUBLIC SERVICE INTERNET

Christian Fuchs 


\section{WELL-BEING AND \\ MENTAL HEALTH IN THE \\ GIG ECONOMY}

POLICY PERSPECTIVES ON PRECARITY

Sally-Anne Gross, George Musgrave and Laima Janciute

A CAMRI POLICY BRIEF

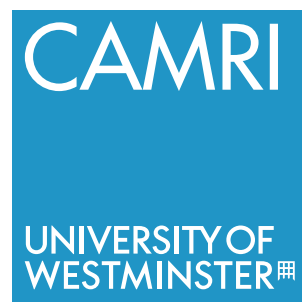




$$
\begin{gathered}
\text { Published by } \\
\text { University of Westminster Press } \\
115 \text { New Cavendish Street } \\
\text { London W1W 6UW } \\
\text { www.uwestminsterpress.co.uk }
\end{gathered}
$$

Text (c) Sally-Anne Gross, George Musgrave and Laima Janciute

First published 2018

Cover: ketchup-productions.co.uk

Digital versions typeset by Siliconchips Services Ltd.

$$
\begin{gathered}
\text { ISBN (Paperback): 978-1-911534-89-1 (not available for sale) } \\
\text { ISBN (PDF): 978-1-911534-90-7 } \\
\text { ISBN (EPUB): 978-1-911534-91-4 } \\
\text { ISBN (Kindle): 978-1-911534-92-1 }
\end{gathered}
$$

DOI: https://doi.org/10.16997/book32

$$
\begin{aligned}
& \text { Series: CAMRI Policy Briefs } \\
& \text { ISSN 2516-5712 (Print) } \\
& \text { ISSN 2516-5720 (Online) }
\end{aligned}
$$

This work is licensed under the Creative Commons Attribution-NonCommercialNoDerivatives 4.0 International License. To view a copy of this license, visit http://creativecommons.org/licenses/by-nc-nd/4.0/ or send a letter to Creative Commons, 444 Castro Street, Suite 900, Mountain View, California, 94041, USA. This license allows for copying and distributing the work, providing author attribution is clearly stated, that you are not using the material for commercial purposes and that modified versions are not distributed.

The full text of this book has been peer-reviewed to ensure high academic standards. For full review policies, see: http://www.uwestminsterpress.co.uk/site/publish/

\section{Competing Interests}

This research on which this Policy Brief is founded was commissioned by Help Musicians UK (Registered charity number 228089). The commissioners had a collaborative role in the design of the study, however, had no role in: the conduct of the study; the collection, analysis and interpretation of data; the decision of the submission of the manuscript; or in the preparation, review or approval of the manuscript. The views expressed here are those of the authors and not those of the commissioners

Suggested citation:

Gross, Sally-Anne, Musgrave, George and Janciute, Laima. 2018 Well-Being and Mental Health in the Gig Economy: Policy Perspectives on Precarity. London: University of Westminster Press. DOI: https://doi.org/10.16997/book32.

$$
\text { License: CC-BY-NC-ND } 4.0
$$

To read the free, open access version of this book online, visit https://doi.org/10.16997/book32 or scan this QR code with your mobile device:

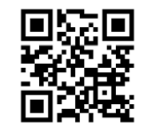




\section{CONTENTS}

Key Messages $\quad 4$

What's the Issue? $\quad 7$

Research Evidence $\quad 12$

Financial Instability 15

The Feedback Economy $\quad 16$

$\begin{array}{ll}\text { Relationships } & 17\end{array}$

Review of Policy Options 20

Increasing Tax for the Self-Employed 20

Policy Recommendations 22

A Universal Basic Income 22

Education is Key 24

Access to Mental Health Support 25

Notes 26

Sources and Further Reading 31 


\section{WELL-BEING AND MENTAL HEALTH INTHE GIG ECONOMY}

\section{? Key Messages}

This policy brief provides research evidence into the working conditions of the UK music industry that indicates the necessity to consider the future of work not only from an economic or employment law perspective, but also in terms of wider societal implications that include the health and well-being of workers.

In the last decade or so, casual, short-term forms of employment have increased significantly. This development has been linked to deindustrialisation and, more generally to the expansion of neoliberal economics globally ${ }^{1}$. These changes have had a significant impact on labour relations as employers have moved away from offering long-term employment contracts favouring instead 'flexible' and freelance work, often based on zero-hours/on-demand contracts.

This mode of employment is now commonly referred to as the gig economy. These working conditions are often described as being particular to the so-called digital economy and its underlying business models. However, long before the arrival of the internet there certainly have been many industries that relied on this 'work for hire' model such as the building trade, agricultural work and many of the skilled trades including areas of cultural labour. However, the creative industries are indeed characterised by these working conditions, where self-employment and short-term project based work have been the norm for decades ${ }^{2}$. 
The research which informs this policy brief suggests that given the expansion of this type of short-term employment, it is important to understand how these working conditions impact on self-employed workers, their families and wider society. This research suggests that:

$>$ Working within these precarious conditions of employment may have psychologically harmful effects.

$>$ Key issues raised by musicians are: financial instability, the requirement to maintain an online presence and network which exposes individuals to relentless opinion and criticism, and the ambiguity of relationships in the music economy with blurry boundaries between friendships and work relationships.

Based on the research evidence of the potential harmful effects that precarious employment conditions may have on the individuals working in it, this policy brief makes the following recommendations:

$>$ The sector of freelance and/or creative self-employment needs to establish health and safety regulations like those that exist in other institutionalised workplaces.

$>$ In order to counter the issues caused by the gig economy, the government should act against the spread of precarious working conditions and promote fair business models. 
$>$ Instead of increasing financial and/or administrative burdens placed on the self-employed, the government should design policies that provide support to workers in the gig economy.

> A universal basic income scheme would enable selfemployed workers to meet their essential needs while staying in their profession.

$>$ Fostering knowledge about mental health amongst workers in the gig economy would enable them to take appropriate action when faced with mental health issues.

$>$ Improving access to mental health support for selfemployed people - with a particular focus on stress and anxiety management - is vital. 


\section{ه WHAT'S THE ISSUE?}

The expansion of the so-called gig economy, where flexible patterns of employment prevail in contrast to permanent jobs, is causing numerous issues. The UK Government's inquiry into Employment Practices in the Modern Economy is a much-needed initiative in response to this trend: the number of self-employed workers in Britain has increased by 1 million between 2008 and $2015^{3}$, while so-called 'zero-hours contracts' have also reached a record high ${ }^{4}$. The transformation in British labour relations and the departure from traditional forms of employment is part of a global trend that has emerged as a result of new technologyenabled business models. This trend is exemplified in the digital economy and the decrease in full-time long-term job offers over the last decade or so. Indeed, according to the Office for National Statistics' most recent report on self-employment: 'the number of self-employed reporting themselves as working on their own, or with a partner but no employees, has increased between 2001 and 2016, while those who report themselves as having employees has fallen over the same period's. This mirrors the conditions frequently found within the music sector. Apart from the increase in earlier forms of flexible work, such as part-time employment or 
fixed-term contracts, new patterns of atypical work contracts and 'on demand' work have also proliferated' .

Work is increasingly being carried out on online platforms connecting buyers and sellers, or by large project teams across borders and time zones [...] Active labourmarket policies are needed to cater for the changing reality in the world of work. This concerns social security systems, which must adapt to new, constantly changing, requirements ${ }^{7}$.

These shifts have given rise to tensions around access to high quality essential services by workers of the gig economy. These include issues such as whether social protection is adequate and sustainable, whether working conditions are fair, whether there is a balance between flexibility and security elements, and what and how high the risks are for both workers and employers ${ }^{8}$. While self-employment is seen as key for economic recovery, innovation and competitiveness, 'the relationship between self-employment and social security has long been problematic, contested and complex'. A recent $\mathrm{BBC}$ article reported on the struggle of a successful blogger and a single parent to qualify for tax credits for example ${ }^{10}$. This case demonstrates how the self-employed have always been evaluated differently under benefit regulations which makes their claims for support more difficult. In the meantime, the UK Parliament's Work and Pensions Committee stated in the context of its inquiry into the gig economy that the expansion of self-employment in many cases is bogus and should be interpreted as the companies' 'free-riding on the welfare state'11. 
Some stakeholders and commentators, including online platforms-based companies, defend the gig economy and flexible employment as a reciprocally beneficial business model, and say that it is only a 'natural future of work' - to be celebrated ${ }^{12}$. They also make claims that offering greater employment benefits would result in less work, overall ${ }^{13}$. Whilst one could argue that self-employment is a matter of choice, it has to be noted that within the creative sector this model of employment is the norm. Although this may offer the self-employed workers a degree of autonomy, it has always left them vulnerable to market changes ${ }^{14}$ as well as changes in income tax and anomalies in social security benefits.

The Uber drivers' case brought to the Employment Tribunal ${ }^{15}$ and other cases ${ }^{16}$ suggest that models of work with reduced social security guarantees are often not desirable from the workers' perspective. The recent UK Parliament Work and Pensions Committee's inquiry, mentioned above, concluded that the growth of the 'gig economy' might be used as a way to escape the welfare state model and that self-employment is often abused. The need to reinforce workers' rights in response to drastic changes in the labour market that have led 'to more temporary jobs and more people being treated as independent contractors ${ }^{17}$ has also been seen internationally. The EU has just presented its proposals addressing this issue ${ }^{18}$ (involving in many cases social dumping and unfair competition) $)^{19}$.

\section{'models of work with reduced social security} guarantees are often not desirable from the workers' perspective' 
Those in favour of the gig economy emphasise the flexibility of this type of work. However, the reality for the workforce is more complex. For low paid self-employed workers, accessing benefits designed to encourage work - such as working tax credits and housing benefits - can be frustratingly time consuming and often futile ${ }^{20}$. Concerns that such working conditions are bad for workers in comparison to full-time workers in permanent employment have been raised on various occasions. Even for higher earning workers self-employment presents difficulties, for example it can cause problems when obtaining financial references and/or statements for renting or mortgages and for other forms of credit which in turn has implications for their spending capacity and national growth. The sustainability of the business and work models of the gig economy can thus be questioned. These trends can be seen clearly in the study outlined below, which also highlights the potentially harmful effects of working within precarious conditions of employment on workers' mental health.

\section{'there is a necessity to consider the future of work not only from an economic or employment \\ law perspective, but also from a well-being perspective too'}

The research suggests that there is a necessity to consider the future of work not only from an economic or employment law perspective, but also from a well-being perspective too. The research findings suggest the potential impact of the gig economy not only on workers' earning potential, but also the potentially negative implication for their health and well-being. 
This policy brief draws particular attention to the impact on the population's mental health caused by precarious forms of work, such as those seen in the gig economy. The link between the two has been observed in various sources ${ }^{21}$, and the evidence in this brief should be understood in the context of this existing scholarship. 


\section{م RESEARCH EVIDENCE}

A detailed insight into the potential links between precarious working conditions such as those seen in the gig economy, and mental health is provided by the research findings from the study 'Can Music Make You Sick? Working Conditions in the UK Music Industry', commissioned in 2016 by the charity Help Musicians $\mathrm{UK}^{*}$ and carried out by Sally-Anne Gross and Dr George Musgrave.

'Can Music Make You Sick?'22 was the largest nationwide study of its kind exploring the psychological impact on musicians of seeking to forge careers within the UK music industry. A survey of over 2200 music industry stakeholders alongside thirty detailed qualitative interviews with artists and industry professionals, demonstrated that there are cripplingly high levels of self-reported depression (68.5\%) and anxiety (71\%) amongst music makers. Crucially, it also explores the source of their mental ill health. The research suggests that the conditions of their self-employment are often the cause of their psychological distress. This research can help to shed light on the conditions of self-employment in the digital age. The music industry's metaphor of the 'canary in a coal mine' was often used to describe the experience of the music 
industries as they faced the technological challenges of the digital era before other parts of the creative industries and in foreshadowing the future of working conditions in the wider economy more generally $^{23}$. Therefore, the way these musicians psychologically experience their self-employment has lessons for other and later workers in the gig economy.

\section{'there are cripplingly high levels of self-reported depression (68.5\%) and anxiety (71\%) amongst music makers.}

The focus of the research was to hear directly from musicians about their working conditions and how they felt these affected their mental well-being. In this first phase, Music Tank, which is part of the University of Westminster, launched an industry-wide survey to ascertain the scale of the potential problem within this
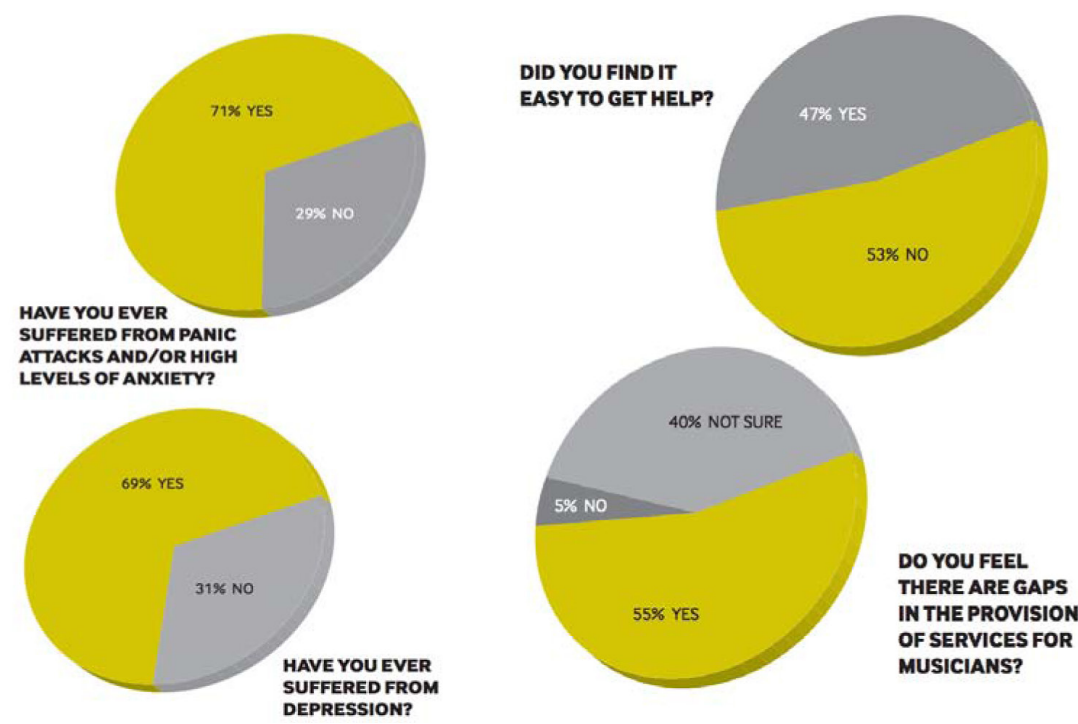
workforce. Comprised primarily of musicians, 2,211 respondents completed the initial survey. Next, the researchers interviewed thirty musicians from across the United Kingdom with the following characteristics:

$>$ An even gender split.

$>$ A wide variety of musical genres (including Pop, Soul, Jazz, Urban, Reggae, Classical, Rock, Dance, Folk, Opera, Dubstep and Musical Theatre).

> Proportionate geographical spread: (London [50\%], Manchester [10\%], Newcastle [8\%], Bristol [8\%], Birmingham [8\%], Edinburgh [4\%], Glasgow [4\%], Belfast [4\%], and Cardiff [4\%]).

$>$ Broad age ranges, and stages in their careers (from artists just starting out to long established professionals).

Alongside this, five supplementary interviews were carried out with record label executives, music managers, and mental health service providers.

Of the survey respondents, $68.5 \%$ reported suffering from depression and $71 \%$ from anxiety. These statistics suggest that these respondents were three times more likely than the general public to suffer from these conditions ${ }^{24}$. Certainly, there is a popular conception of a musician as a 'tortured artist' and, anecdotally, this leads many to perhaps suspect numbers like this because, 'of course all artists are mad'. However, a crucial finding from this research suggests that many musicians and music professionals 
locate the source of their mental ill health in the conditions of their career. Whilst some of our findings related to the specific struggles and strains of a musical career, a number are equally applicable to other forms of insecure employment. Key points suggested by respondents included:

\section{Financial Instability}

For many, the financial precariousness that characterises a career in the music industry - based on varying levels of income, inconsistent contracts, and frequently working for free, is profoundly psychologically destabilising. The inability to turn what appeared to be reasonable levels of perceived success into any financial peace of mind deeply worries these workers. These kinds of concerns stem at least in part from the inability to plan one's future: as one explained 'not quite being able to set goals that are concrete means it's hard to plan' (Folk singer, Cardiff). For many, this means prolonged periods of time living in unstable rental accommodation or having to live at a parental home. It also means worrying month to month about being paid on time as payment for invoices was late, or even not finding any paid work at all.

\section{'The inability to turn what appeared to be reasonable levels of perceived success into any financial peace of mind deeply worries these workers.'}

This creates what is, for many, seen as a kind of extended adolescence where they struggle to achieve crucial markers of adulthood, which in turn harms their self-esteem, leading to profound feelings of both anxiety and depression. Musicians spoke 
of seeing their peers achieving crucial 'life goals' such as buying houses, getting married, and going on holidays, and their creeping sense of self-doubt leading to feelings of depression. Interviewees often described a 'relentless' pressure that they felt to stay afloat, which manifests itself in exhaustion, but also simultaneously, feelings of 'guilt' and anxiety about taking any time off.

'What might be thought of as liberation, is experienced as detachment; flexibility as fragility;

geographical mobility as placelessness or rootlessness; and the freedom of freelancing as anxiety.'

To suggest that musicians struggle financially is of course not new or novel. However, what the research findings of 'Can Music Make You Sick' point towards, is a greater acknowledgement of the relationship between financial precarity and emotional instability. Indeed, the author whose work inspires a great deal of contemporary thinking surrounding the impact of precarity Guy Standing - spoke in his work of 'the precariatised mind'25. It is important to consider how a loss of financial certainty has widereaching psychological ramifications for workers. What might be thought of as liberation is experienced as detachment; flexibility as fragility; geographical mobility as placelessness or rootlessness; and the freedom of freelancing as anxiety.

\section{The Feedback Economy}

For these types of workers, having a presence and a network online is fundamental. The entrepreneurial creation of a brand, seeking new work contracts, and staying connected with others 
given the lack of any fixed place of work, is central. However, a great number of our interviewees suggested that their anxiety concerned the fact their working lives took place within a feedback economy of relentless opinion and criticism. These workers criticise their own work, others criticise their work, they criticise themselves when comparing themselves to the successes of others, and in doing so, compare themselves to a version of themselves which they imagined they might be. In a hyper-mediated world of the internet, this feedback loop is infinite.

Musicians talked about the difficulties of managing the torrent of feedback (both good and bad) - something which has received attention for its harmful impact on young people and particularly young girls ${ }^{26}$ and women. Related to this, social media was often the vehicle through which they would observe the achievements of others, and would come to compare their own fortunes to that of their peers and competitors. This could drastically harm the self-esteem of these workers who, as suggested, had often spent years or even decades struggling in an environment of insecure housing and negligible/non-existent wages, and who could, at times, conceptualise these discrepancies as profound failures.

\section{Relationships}

The music industry is a highly networked industry and one's social and physical geographical location within this network plays a significant part in workers' ability to secure work or even to compete for work, and many of the musicians we interviewed talked about the problem of the London-centric character of the music industry despite the new digital practices. It was still very much expressed that you needed to be embedded within a network to get 
noticed and this was very frustrating for those who lived outside of the capital. London was felt by many to be just too expensive for them to exist in, yet without being there they felt their chances diminished. On the other hand, the relaxed and informal working culture in the creative industries, and freelance work more generally, is what many find attractive about it. However, many interviewees spoke of the blurring of relationship boundaries and the difficulty in distinguishing 'friends' from 'colleagues'. This inability to tell when one was in a work environment or a social environment leads them, at times, to question the authenticity of their friendships and also made several feel that they were being emotionally manipulated into working for free on occasion because it was a 'friends thing. These ambiguous relationships seemed to add to the musicians' frustrations and feelings of inadequacy, and added to their anxiety.

This research suggests that freelance and/or creative selfemployment, typical of that found in the wider gig economy, has a number of psychologically harmful components that should be acknowledged. Where the 'creative' self-employed may find comfort and also satisfaction in their creative capacity that serves to offset some of the issues surrounding their precarious conditions, increasingly the new members of the gig economy who lack the potential cushion of creative capacity and fulfilment are faced only with the constraints and pressures of these conditions.

Central to these findings is the impact of precarious work on the well-being of workers. This type of work therefore suffers not only from a precarity of finances, but also a precarity of status, a precarity of certainty, and a precarity of sociality. As suggested, a 
number of the findings in 'Can Music Make You Sick' are relatively unique to the vicissitudes and challenges of a musical career. However, a number of these features of freelance, independent, and entrepreneurial musical work, are experienced by other freelance workers both in the digital economy and in the gig economy too.

\section{'This type of work therefore suffers not only from a precarity of finances, but also a precarity of status, a precarity of certainty, and a precarity of sociality'}

It is vital to acknowledge the emotional dimension of precarity. Just as other institutionalised workplaces have health and safety regulations, so too must this form of employment. Workers engaged in self-employment of this kind can be economically precarious, emotionally vulnerable, and suffer interpersonally. Genuine consideration must be given to the psychological dimensions of this style of work, as highlighted by this research. 


\section{局 REVIEW OF POLICY OPTIONS}

\section{Increasing Tax for Self-Employed}

Recently, the UK Government considered a tax increase for the self-employed that, after a remarkable public outcry, was later abandoned. As aforementioned, the precarious conditions of employment and the underlying uncertainty of the likely levels of income and social security benefits generate a series of tensions with which a 'flexible worker' is left to cope. Tax rates are part of the ecosystem of self-employment that should be designed in the way that supports the well-being of the self-employed rather than creating new challenges. The above research indicates that the conditions of self-employment are often the cause of psychological distress. Based on that, heavier tax duties, as a source of additional challenges, would not work towards improving the mental health issues frequently inherent to flexible patterns of work, which in turn might have various societal implications due to their impact on productivity and the stability of family lives, and in other respects. It is also worth mentioning that the creative industries - the category under which the sample of the study 'Can Music Make You Sick?' falls - where freelancing or other patterns of flexible work are widespread, have been so far disadvantaged 
as compared with other sectors in terms of the overall support and attention assigned in public policy, as articulated in the current debates around the Government's Industrial Strategy Green Paper $(2017)^{27}$. Indeed, the modal earnings of the self-employed more generally vis-à-vis employees are typically far lower; around $£ 240$ per week as opposed to $£ 400$ per week ${ }^{28}$. Furthermore whilst some in what the Office for National Statistics calls 'full-time self employment' do indeed earn high salaries, it is important to note that they do so without the benefits of formalised employment and the associated protections afforded by it. Therefore, we propose that the Government should avoid actions that will place more financial and/or administrative burdens on the self-employed. The Government should direct its efforts in designing policies that support this category of the workforce, which operates in continuous uncertainty with regards to income and work employment. 


\section{$\nabla$ POLICY RECOMMENDATIONS}

\section{A Universal Basic Income}

These findings suggest, more generally, that the Government should consider policies that disincentivise the spread of working arrangements that result in precarious working conditions. Such initiatives should be supplemented with revisions to work contracts which seek to avoid the granting of basic employment rights. These might be developed alongside new expanded contractual conditions that could, for example, include time spent working (hours), output of work and/or reflect a product or service's value and income ultimately earned as a result - all along more equitable lines. This paper will explore the viability of a bolder policy suggestion - that of a Universal Basic Income. The concept of a Universal Basic Income (UBI) refers to an income paid to all individuals within a prescribed area such as a nation state, which is entirely non-means tested and received without stipulations or requirements of any kind. Conceptually, there are two distinct versions of the UBI. The neoliberal version suggests that everyone receives a small amount per month but that this should coincide with the dismantling of the welfare state. The progressive version suggests funding UBI out of capital taxation, i.e. 
to tax capital and redistribute capital (which is conceptualised as surplus-value generated by workers) to all citizens. In the United Kingdom, the Green Party introduced a commitment to the concept in their 2017 manifesto $^{29}$. The argument proposed herein, is to consider the idea that a progressive Universal Basic Income might be of immense psychological and emotional benefit for workers in the gig economy, the UK music industry, and indeed in the wider economy. In this sense, we simply seek to reframe the debate around UBI, suggesting that it has a psychological component which should be considered.

The scope of this brief does not allow for a meaningful discussion of the pros and cons of implementing a policy of UBI more generally - see Downes (2018) for a comprehensive overview. Instead, the insights offered are intended only to provide another dimension to the debate surrounding the potential benefits of such a scheme. These are multiple, and include the idea that UBI has:

$>$ ethical and moral benefits, in terms of compensating for the job losses caused by automation, or facilitating self-development and the establishment of universal self-respect;

$>$ economic benefits, in terms of efficiency savings as hugely complex and bureaucratic systems of welfare payments are effectively dismantled, or via the boost in aggregate demand in the economy;

$>$ political and democratic benefits, in terms of improving levels of political and civic engagement - see Fuchs (2008) for more details. 
Our suggestion is that a progressive UBI also may have psychological benefits, because it alleviates the emotional burden of precarity, which increasingly shapes the nature of contemporary work. It is important of course to be pragmatic and consider short-term practicalities and the realities of trying to implement a system based on $\mathrm{UBI}^{30}$.

In the absence of Universal Basic Income being meaningfully considered by the UK Government at this stage, this Policy Brief makes two further policy recommendations.

\section{Education is Key}

Ensuring a greater awareness of the mental health challenges facing those working within the gig economy is vital. These educational processes need to take place on a variety of levels. Within higher education and elsewhere, there needs to be a concerted effort to embed mental health within the curriculum of the courses on offer, to ensure awareness of the challenges that individuals might face, and enable those likely to be employed as flexible workers to take appropriate steps to prepare themselves for this work environment. Courses which feature an entrepreneurial component, or which have a graduate employment composition featuring the types of work discussed in this policy brief - for example fashion, journalism, the wider creative industries - should seek to engage students in debates surrounding the links between the challenges of the working conditions they might face in their working lives and the potential psychological ramifications of this work. 


\section{Access to Mental Health Support}

Access to (and funding of) mental health support for selfemployed people should be improved, paying particular attention to stress and anxiety management. It was hugely encouraging that following the publication of 'Can Music Make You Sick', a dedicated 24/7 telephone support service was launched for the music industry on the basis of our recommendations. This service - Music Minds Matter - launched by Help Musicians UK, might act as a benchmark against which other industries might draw inspiration, particularly those with relatively weak trade union membership which typifies a great deal of work within the gig economy. Further research is of course required to gauge the impact of this and other mental health support services. 


\section{国 NOTES}

* Disclaimer: this document should be regarded as an individual submission by the authors, not representing an official position of the MusicTank/University of Westminster nor the opinions of the research commissioners Help Musicians UK.

${ }^{1}$ Fuchs, C. 2014. Digital Labour and Karl Marx; Abingdon: Routledge.

${ }^{2}$ Banks, M. 2017 Creative Justice: Cultural Industries, Work and Inequality. Rowman and Littlefield International; Cloonan, M \& Williamson, J. 2016. Players' Work Time: A History of the British Musicians' Union, 1893-2013. Oxford: Oxford University Press; Hesmondhalgh, D. 2012. The Cultural Industries, London: Sage; McRobbie, A. 1999. In the Culture Society: Art, Fashion and Popular Music, London: Psychology Press.

${ }^{3}$ ONS. Trends in self-employment in the UK: 2001 to 2015. 2016: https://www.ons.gov.uk/employmentandlabourmarket/ peopleinwork/employmentandemployeetypes/articles/trendsi nselfemploymentintheuk/2001 to2015 (accessed May 2017).

${ }^{4}$ ONS. Contracts that do not guarantee a minimum number of hours: May 2017. 2017: https://www.ons.gov.uk/employment andlabourmarket/peopleinwork/earningsandworkinghours/ articles/contractsthatdonotguaranteeaminimumnumberof hours/may2017 (accessed May 2017).

${ }^{5}$ ONS. 2018. Trends in self-employment in the UK: Analysing the characteristics, income and wealth of the self-employed: 
https://www.ons.gov.uk/employmentandlabourmarket/people inwork/employmentandemployeetypes/articles/trendsin selfemploymentintheuk/2018-02-07 (accessed June 2018).

${ }^{6}$ EP Briefing: The future of work in the EU. 2017: http://www. europarl.europa.eu/RegData/etudes/BRIE/2017/599426/ EPRS_BRI(2017)599426_EN.pdf (accessed May 2017).

${ }^{7}$ EP Briefing: The future of work in the EU. 2017: http://www. europarl.europa.eu/RegData/etudes/BRIE/2017/599426/ EPRS_BRI(2017)599426_EN.pdf (accessed May 2017).

${ }^{8}$ Ibid.

9 SSAC Occasional Paper 13: Social security and the selfemployed. 2014: https://www.gov.uk/government/uploads/ system/uploads/attachment_data/file/358334/Social_security_ provision_and_the_self-employed_FINAL_24_SEPT_.pdf (accessed April 2017).

${ }^{10}$ Kleinman, Z. Blogger fury over tax credit rejection. 2016: http://www.bbc.co.uk/news/technology-37275604 (accessed April 2017).

${ }^{11}$ WPC. 'Gig economy' companies free-riding on the welfare state. 2017: http://www.parliament.uk/business/committees/ committees-a-z/commons-select/work-and-pensions-committee/ news-parliament-2015/gig-economy-report-published-16-17/ (accessed May 2017).

${ }^{12}$ BBC Gig economy chiefs defend business model. 2017: http:// www.test.bbc.co.uk/news/business-39051721 (accessed May 2017); Dizik, A., The next generation of jobs won't be made up of professions (2017): http://www.bbc.com/capital/ story/20170424-the-next-generation-of-jobs-wont-be-madeup-of-professions (accessed May 2017); RSA The evidence proves self-employment is great. Celebrate it! Press release. 2014: https://www.thersa.org/discover/publications-and-articles/ rsa-blogs/2014/04/the-evidence-proves-self-employment-isgreat.-celebrate-it (accessed May 2017), etc. 
${ }^{13}$ BBC Gig economy chiefs defend business model. 2017: http:// www.test.bbc.co.uk/news/business-39051721 (accessed May 2017).

${ }^{14}$ SSAC Occasional Paper 13: Social security and the selfemployed. 2014: https://www.gov.uk/government/uploads/ system/uploads/attachment_data/file/358334/Social_ security_provision_and_the_self-employed_FINAL_24_ SEPT__.pdf (accessed April 2017); EP Briefing: The future of work in the EU (2017): http://www.europarl.europa.eu/ Reg D a t a / e t u d e s / B R I E / 2017 / 599426 / E P R S BRI(2017)599426_EN.pdf (accessed May 2017).

${ }^{15}$ ET Case 2202550/2015 \& Others. 2016: https://www. judiciary.gov.uk/wp-content/uploads/2016/10/aslam-andfarrar-v-uber-reasons-20161028.pdf (accessed April 2017).

${ }^{16} \mathrm{BBC}$ Bike courier wins 'gig' economy employment rights case. 2017: http://www.bbc.co.uk/news/business-38534524 (accessed April 2017); RCJ Case No: A2/2015/0196 Pimlico Plumbers (2017): https://www.judiciary.gov.uk/wp-content/ uploads/2017/02/pimlico-plumbers-v-smith.pdf (accessed April 2017). The Supreme Court (UK) (2018) Pimlico Plumbers Ltd and another (Appellants) v Smith (Respondent), Case ID UKSC 2017/0053: https://www.supremecourt.uk/cases/uksc2017-0053.html (accessed June 2018)

${ }^{17}$ EP Employment: MEPs to discuss plans to reinforce workers' rights. 2017: http://www.europarl.europa.eu/news/en/newsroom/20170407STO70803/employment-meps-to-discussplans-to-reinforce-workers'-rights (accessed 2017).

${ }^{18}$ EC The European Pillar of Social Rights in 20 principles. 2017: https://ec.europa.eu/commission/priorities/deeperand-fairer-economic-and-monetary-union/european-pillarsocial-rights/european-pillar-social-rights-20-principles_en (accessed May 2017).

${ }^{19}$ EP Employment: MEPs to discuss plans to reinforce workers' rights. 2017: http://www.europarl.europa.eu/news/en/news- 
room/20170407STO70803/employment-meps-to-discussplans-to-reinforce-workers'-rights (accessed 2017).

${ }^{20}$ WPC 'Gig economy' companies free-riding on the welfare state. 2017: http://www.parliament.uk/business/committees/ committees-a-z/commons-select/work-and-pensionscommittee/news-parliament-2015/gig-economy-reportpublished-16-17/ (accessed May 2017); Hutton, W., The gig economy is here to stay. So making it fairer must be a priority. 2016: https:/www.theguardian.com/commentisfree/2016/sep/ 03/gig-economy-zero-hours-contracts-ethics (accessed April 2017).

${ }^{21}$ Among which EP Briefing: The future of work in the EU. 2017: http://www.europarl.europa.eu/RegData/etudes/ BRIE/2017/599426/EPRS_BRI(2017)599426_EN.pdf (accessed May 2017); Hutton, W., The gig economy is here to stay. So making it fairer must be a priority, The Guardian 2016: https:// www.theguardian.com/commentisfree/2016/sep/03/gigeconomy-zero-hours-contracts-ethics (accessed April 2017); Tolento, J., The gig economy celebrates working yourself to death, The New Yorker 2017: http://www.newyorker.com/ culture/jia-tolentino/the-gig-economy-celebrates-workingyourself-to-death (accessed May 2017); De Gallier, T. Freelancing made my depression worse, The Guardian 2017: https://www. theguardian.com/careers/2017/may/09/freelancing-made-mydepression-worse-heres-how-i-learnt-to-cope (accessed May 2017); Moscone, F., Tosetti, E., Vittadini, G. 2016. The Impact of Precarious Employment on Mental Health: The Case of Italy, Social Science and Medicine, Vol. 158, pp. 86-95, etc.

${ }^{22}$ Gross, S \& Musgrave, G. 2016. Can Music Make You Sick? Music and Depression. A Study into the Incidence of Musicians' Mental Health. Part 1 - Pilot Survey Report, Harrow: MusicTank; Gross, S \& Musgrave, G. 2017. Can Music Make You Sick? A Study into the Incidence of Musicians' Mental Health Part 2: Qualitative Study and Recommendations. Harrow: MusicTank.

${ }^{23}$ Attali, J. 1977. Bruits: Essai Sur L'Economie Politique de la Musique: Paris: Presses Universitaires de France. 
${ }^{24}$ According to the ONS (2013), nearly 1 in 5 (19\%) of people in the UK aged 16 years or over experienced anxiety or depression (using the GHQ method which asked if they had experienced these things 'recently') in 2010-11. This was consistent across the two subsequent years for which ONS data is available (ONS, 2015 ), with $18.3 \%$ of people (nearly 1 in 5) similarly responding in both 2011-12, and again in 2012-13. Source: ONS Measuring National Well-being: Health, 2013 (2013): http://webarchive. nationalarchives.gov.uk/20160105160709/http://www.ons.gov. uk/ons/dcp171766_310300.pdf (accessed Sept 2016); ONS Measuring National Well-being: Life in the UK, 2015 (2015): http://webarchive.nationalarchives.gov.uk/20160105160709/ http://www.ons.gov.uk/ons/dcp171766_398059.pdf (accessed Sept 2016).

${ }^{25}$ Standing, G. 2016. The Precariat: The New Dangerous Class. London: Bloomsbury Publishing.

${ }^{26}$ Valkenburg, P.M., Peter, J., Schouten, A.P. 2006. Social Networking Sites and Their Relationship to Adolescents WellBeing and Social Self-Esteem, CyberPsychology and Behavior, Vol. 9(5), pp. 584-590.

${ }^{27}$ BBC Industrial strategy 'must help' UK creative industries. 2017: http://www.bbc.co.uk/news/business-39604320 (accessed May 2017).

${ }^{28}$ ONS. 2018. Trends in self-employment in the UK: Analysing the characteristics, income and wealth of the self employed: https://www.ons.gov.uk/employmentandlabourmarket/people inwork/employmentandemployeetypes/articles/trendsin selfemploymentintheuk/2018-02-07 (accessed June 2018)

${ }^{29}$ Green Party. 2017. Manifesto: The Green Party for a Confident and Caring Britain: https://www.greenparty.org.uk/assets/ files/gp2017/greenguaranteepdf.pdf (accessed June 2018).

${ }^{30}$ Van Parjis, P \& Vanderborght, Y. 2017. Basic Income: A Radical Proposal for a Free Society and a Sane Economy. Cambridge, MA: Harvard University Press. 


\section{曹 SOURCES AND FURTHER READINGS}

Attali, J. 1977 Bruits: Essai Sur L'Economie Politique de la Musique. Paris: Presses Universitaires de France.

Banks, M. 2017 Creative Justice: Cultural Industries, Work and Inequality. London: Rowman and Littlefield International.

BBC. 2017 Bike courier wins 'gig' economy employment rights case: http://www.bbc.co.uk/news/business-38534524 (accessed April 2017)

BBC. 2017. Industrial strategy 'must help' UK creative industries: http://www.bbc.co.uk/news/business-39604320 (accessed May 2017

BBC. 2017. Gig economy chiefs defend business model: http:// www.test.bbc.co.uk/news/business-39051721 (accessed May 2017)

Cloonan, M \& Williamson, J. 2016. Players' Work Time: A History of the British Musicians' Union, 1893-2013. Oxford: Oxford University Press.

De Gallier, T. 2017 Freelancing made my depression worse, The Guardian: https:/www.theguardian.com/careers/2017/ may/09/freelancing-made-my-depression-worse-heres-how-ilearnt-to-cope (accessed May 2017).

Dizik, A. 2017. The next generation of jobs won't be made up of professions: http://www.bbc.com/capital/story/20170424-the- 
next-generation-of-jobs-wont-be-made-up-of-professions (accessed May 2017).

Downes, A. 2018. It's Basic Income: The Global Debate Bristol: Policy Press.

EC. 2017. The European Pillar of Social Rights in 20 principles: https://ec.europa.eu/commission/priorities/deeper-and-fairereconomic-and-monetary-union/european-pillar-social-rights/ european-pillar-social-rights-20-principles_en (accessed May 2017).

EP. 2017. Briefing: The Future of Work in the EU: http://www. europarl.europa.eu/RegData/etudes/BRIE/2017/599426/ EPRS_BRI(2017)599426_EN.pdf (accessed May 2017).

EP. 2017. Employment: MEPs to discuss plans to reinforce workers' rights: http://www.europarl.europa.eu/news/en/news-room/ 20170407STO70803/employment-meps-to-discuss-plans-toreinforce-workers'-rights (accessed 2017).

ET. 2016. Case 2202550/2015 \& Others: https://www.judiciary. gov.uk/wp-content/uploads/2016/10/aslam-and-farrar-vuber-reasons-20161028.pdf (accessed April 2017).

Fuchs, C. 2008. Foundations and Two Models of Guaranteed Basic Income. In Perspectives on Work, eds. Otto Neumaier, Gottfried Schweiger and Clemens Sedmak, pp. 235-248. Wien-Münster: LIT Verlag.

Fuchs, C. 2014. Digital Labour and Karl Marx. Abingdon: Routledge

Green Party. 2017. Manifesto: The Green Party for a Confident and Caring Britain: https://www.greenparty.org.uk/assets/files/ gp2017/greenguaranteepdf.pdf (Accessed June 2018)

Gross, S \& Musgrave, G. 2016. Can Music Make You Sick? Music and Depression. A Study into the Incidence of Musicians' Mental Health. Part 1 - Pilot Survey Report, Harrow: MusicTank 
Gross, S \& Musgrave, G. 2017. Can Music Make You Sick? A Study into the Incidence of Musicians' Mental Health Part 2: Qualitative Study and Recommendations. Harrow: MusicTank.

Hesmondhalgh, D. 2012 The Cultural Industries. London: Sage.

Hutton, W. 2016. The gig economy is here to stay. So making it fairer must be a priority, The Guardian: https://www.the guardian.com/commentisfree/2016/sep/03/gig-economyzero-hours-contracts-ethics (accessed April 2017).

Kleinman, Z. 2016. Blogger fury over tax credit rejection: http:// www.bbc.co.uk/news/technology-37275604 (accessed April 2017).

McRobbie, A. 1999. In the Culture Society: Art, Fashion and Popular Music, London: Psychology Press

Moscone, F., Tosetti, E. \& Vittadini, G. 2016. The Impact of Precarious Employment on Mental Health: The Case of Italy, Social Science and Medicine, Vol. 158, pp. 86-95.

ONS. 2013 Measuring national well-being: health, 2013: http:// webarchive.nationalarchives.gov.uk/20160105160709/http:// www.ons.gov.uk/ons/dcp171766_310300.pdf (accessed Sept 2016).

ONS. 2015. Measuring national well-being: Life in the UK, 2015: http://webarchive.nationalarchives.gov.uk/20160105160709/ http://www.ons.gov.uk/ons/dcp171766_398059.pdf (accessed Sept 2016).

ONS. 2016. Trends in self-employment in the UK: 2001 to 2015: https://www.ons.gov.uk/employmentandlabourmarket/ peopleinwork/employmentandemployeetypes/articles/trendsi nselfemploymentintheuk/2001 to2015 (accessed May 2017).

ONS. 2017. Contracts that do not guarantee a minimum number of hours: May 2017: https://www.ons.gov.uk/employmentand labourmarket/peopleinwork/earningsandworkinghours/ 
articles/contractsthatdonotguaranteeaminimumnumber ofhours/may2017 (accessed May 2017).

ONS. 2018. Trends in self-employment in the UK: Analysing the characteristics, income and wealth of the self employed: https:// www.ons.gov.uk/employmentandlabourmarket/peopleinwork/ employmentandemployeetypes/articles/trendsinselfemploy mentintheuk/2018-02-07 (Accessed June 2018)

RCJ. 2017. Case No: A2/2015/0196 Pimlico Plumbers: https:// www.judiciary.gov.uk/wp-content/uploads/2017/02/pimlicoplumbers-v-smith.pdf (accessed April 2017).

RSA. 2014. The evidence proves self-employment is great. Celebrate it! Press release:https://www.thersa.org/discover/ publications-and-articles/rsa-blogs/2014/04/the-evidenceproves-self-employment-is-great.-celebrate-it (accessed May 2017).

SSAC. 2014. Occasional Paper 13: Social security and the self-employed: https://www.gov.uk/government/uploads/ system/uploads/attachment_data/file/358334/Social_security_ provision_and_the_self-employed_FINAL_24_SEPT_.pdf (accessed April 2017).

Standing, G. 2016. The Precariat: The New Dangerous Class. London: Bloomsbury Publishing

The Supreme Court (UK). 2018. Pimlico Plumbers Ltd and another (Appellants) v Smith (Respondent), Case ID UKSC 2017/0053: https://www.supremecourt.uk/cases/uksc-20170053.html (Accessed June 2018)

Tolento, J. 2017. The gig economy celebrates working yourself to death, The New Yorker: http://www.newyorker.com/culture/ jia-tolentino/the-gig-economy-celebrates-working-yourselfto-death (accessed May 2017).

Valkenburg, P.M., Peter, J. \& Schouten, A.P. 2006. Social Networking Sites and Their Relationship to Adolescents Well-Being and 
Social Self-Esteem, CyberPsychology and Behavior, Vol. 9(5), pp. 584-590.

Van Parjis, P \& Vanderborght, Y. 2017 Basic Income: A Radical Proposal for a Free Society and a Sane Economy. Cambridge, MA: Harvard University Press

WPC. 2017. 'Gig economy' companies free-riding on the welfare state: http://www.parliament.uk/business/committees/ committees-a-z/commons-select/work-and-pensionscommittee/news-parliament-2015/gig-economy-reportpublished-16-17/ (accessed May 2017). 


\section{WELL-BEING AND MENTAL HEALTH IN THE GIG ECONOMY}

\section{Policy Perspectives on Precarity}

A response is needed to the numerous issues spurred by the expansion of the gig economy, where flexible patterns of employment prevail in contrast to permanent jobs. In this context of the exponential growth of the digital economy and underlying business models the largest nationwide study of its kind into the

impact of the working conditions in the UK music industry

'Can Music Make You Sick?' has been conducted by MusicTank/University of Westminster.

This research suggests the need to consider the future of work not only from an economic or employment law perspective but from a mental health one too. What are the psychological implications of precarious work and how are factors such as financial instability, the feedback economy and personal relationships reflected in mental health outcomes or connected to the business relationships most musicians and other gig economy participants work under?

Authors Sally-Anne Gross, George Musgrave and Laima Janciute consider which policy measures may help or harm gig economy workers including the taxation of self-employed workers, a universal basic income, education around mental health issues and access to mental health support.

www.uwestminsterpress.co.uk 